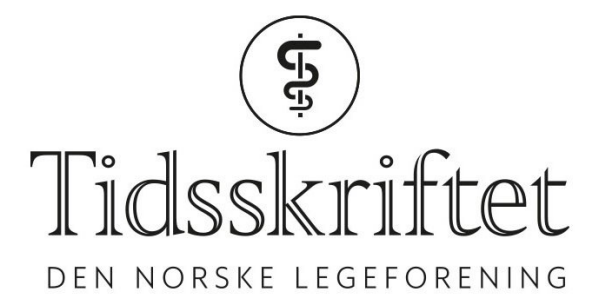

\title{
Basalcellekarsinomer i ansiktet feilbehandles for ofte
}

DEBATTARTIKLER

INGRID ROSCHER

E-post: INROSC@ous-hf.no

Ingrid Roscher er spesialist i hud- og veneriske sykdommer og overlege med særlig ansvar for behandling av hudkreft.

Forfatteren har fylt ut ICMJE-skjemaet og oppgir ingen interessekonflikter.

\section{TRINE BREVIG}

Trine Brevig er spesialist i patologi og overlege med særlig ansvar for hudpatologi og diagnostikk ved komplisert tumorkirurgi i ansikt.

Forfatteren har fylt ut ICMJE-skjemaet og oppgir ingen interessekonflikter.

\section{PETTER GJERSVIK}

Petter Gjersvik er spesialist i hud- og veneriske sykdommer, professor og medisinsk redaktør i Tidsskriftet.

Forfatteren har fylt ut ICMJE-skjemaet og oppgir ingen interessekonflikter.

Fotodynamisk terapi og annen destruktiv behandling av hudkreft kan føre til residiv og omfattende kirurgiske inngrep.

Basalcellekarsinom har flere kliniske uttrykksformer, vokser langsomt, metastaserer svært sjelden og er oftest lett å behandle. Flere behandlingsmetoder er aktuelle: kirurgisk eksisjon og destruktive metoder, slik som kryobehandling, fotodynamisk terapi, avskrapning (curettage) kombinert med kauterisering og kjemisk ablasjon, foruten immunmodulerende topikal behandling $(1,2)$. Risikoen for residiv kan være stor ved valg av feil behandlingsmetode. Ved Seksjon for hudsykdommer, Oslo universitetssykehus får vi henvist mange pasienter med residiv av basalcellekarsinom etter behandling med destruktive metoder, inkludert fotodynamisk behandling, som er i strid med etablerte retningslinjer $(1,2)$. Slike svulster skulle vært behandlet med kirurgi.

Det er vanlig å betegne superfisielle og nodulære basalcellekarsinomer for lesjoner med lav risiko for residiv, mens skleroserende/morfeiforme/infiltrerende basalcellekarsinomer og basoskvamøse karsinomer, som har et mer aggressivt vekstmønster, betegnes som lesjoner med høy risiko for residiv (1). Alle basalcellekarsinomer i den såkalte H-sonen i ansiktet, dvs. sentralt i ansiktet, tinninger og preaurikulært, regnes også som lesjoner med høy risiko for residiv. I tillegg har alle residivsvulster $\emptyset \mathrm{kt}$ risiko for å residivere.

\section{Mange behandlingsformer}

Et superfisielt basalcellekarsinom kan behandles med kirurgi eller med destruktive 
metoder $(1,2)$. Et nodulært basalcellekarsinom bør fjernes kirurgisk, men hvis tumortykkelsen er $<2 \mathrm{~mm}$, kan destruktive metoder vurderes. Risikoen for residiv er imidlertid lavest etter eksisjon (3).

Ved bruk av destruktive metoder kan resultatet se fint ut på overflaten for en periode, men hvis tumor ikke er radikalt fjernet, kan en svulst med aggressivt vekstmønster fortsette å vokse ned i dypet og ut til sidene

Skleroserende/morfeiforme/infiltrerende basalcellekarsinomer og basoskvamøse karsinomer er oftest lokalisert i ansiktet (4). Den kliniske avgrensningen av slike svulster er ofte vanskelig å fastslå. De kan vokse infiltrerende med lange utløpere til sidene og/eller i dypet. Dette kan også være tilfelle for nodulære basalcellekarsinomer. Slike lesjoner må derfor biopseres før behandling for å kartlegge histologiske karakteristika, vekstmønster, tykkelse og utbredelse. Når et basalcellekarsinom har trekk fra flere subtyper, noe som er vanlig, må valg av behandling baseres på den mest aggressive histologiske komponenten.

Ved bruk av destruktive metoder kan resultatet se fint ut på overflaten for en periode, men hvis tumor ikke er radikalt fjernet, kan en svulst med aggressivt vekstmønster fortsette å vokse ned i dypet og ut til sidene under epidermis før residivsvulsten blir synlig klinisk. Når svulsten så viser seg på overflaten, trenger pasienten ofte omfattende kirurgiske inngrep med negative følger for funksjon og utseende. Dette er en stor belastning for pasienten, ressurskrevende for helsevesenet og dyrt for samfunnet.

\section{Riktig behandling for riktig pasient}

Før behandling av et basalcellekarsinom, spesielt i ansiktet, må lesjonen vurderes nøye. Ved residivsvulster og dersom diagnosen superfisielt basalcellekarsinom er usikker ved klinisk og dermatoskopisk undersøkelse, må man ta en stansebiopsi (helst $\geq 3 \mathrm{~mm}$ bred og dypt nok) for at patolog skal kunne angi subtype, vekstmønster og tykkelse. Kyrettert materiale, tangentiell biopsi (shave biopsy) og cytologisk prøve er ikke godt nok.

Først når et slikt biopsisvar foreligger, kan man velge behandlingsform. For basalcellekarsinom med høy risiko for residiv er Mohs' mikrografiske kirurgi den beste behandlingen, spesielt når svulsten er uskarpt avgrenset eller sitter i H-sonen (5). Ved denne metoden foretas peroperativ histologisk vurdering av horisontale frysesnitt som grunnlag for å utvide reseksjonen der det påvises tumorrester. På den måten sikres radikal fjerning av tumor samtidig som man sparer mest mulig friskt vev. Vanlig eksisjon med adekvate marginer er et godt alternativ, eventuelt som «åpen» behandling der sårdefekten ligger åpen i påvente av patologens klarering av reseksjonsflatene. Patologens svar må inneholde informasjon om tumors subtype, tykkelse, vekstmåte og avstand til siderender og bunn. Alle former for destruktiv behandling, også fotodynamisk behandling, er kontraindisert ved slike basalcellekarsinomer.

Det fremheves ofte at fotodynamisk behandling gir et pent kosmetisk resultat, men dette gjelder ikke ved basalcellekarsinomer med et aggressivt vekstmønster. Ved destruktiv behandling av slike svulster i ansiktet vil det motsatte skje: Man får residivsvulster som krever omfattende kirurgi, og et dårlig kosmetisk sluttresultat.

LITTERATUR:

1. Peris K, Fargnoli MC, Garbe C et al. Diagnosis and treatment of basal cell carcinoma: European consensus-based interdisciplinary guidelines. Eur J Cancer 2019; 118: 10-34. [PubMed][CrossRef]

2. Christensen E, Warloe T, Kroon S et al. Guidelines for practical use of MAL-PDT in non-melanoma skin cancer. J Eur Acad Dermatol Venereol 2010; 24: 505-12. [PubMed][CrossRef]

3. Collier NJ, Haylett AK, Wong TH et al. Conventional and combination topical photodynamic therapy for basal cell carcinoma: systematic review and meta-analysis. Br J Dermatol 2018; 179: 1277-96.

[PubMed][CrossRef] 
4. Scrivener Y, Grosshans E, Cribier B. Variations of basal cell carcinomas according to gender, age, location and histopathological subtype. Br J Dermatol 2002; 147: 41-7. [PubMed][CrossRef]

5. Roscher I, Brevig T, Mørk G et al. Mohs' kirurgi ved basalcellekarsinom i ansiktet. Tidsskr Nor Legeforen 2011; 131: 2475-9. [PubMed][CrossRef]

Publisert: 28. juni 2021. Tidsskr Nor Legeforen. DOI: 10.4045/tidsskr.21.0282

Mottatt 6.4.2021, første revisjon innsendt 20.4.2021, godkjent 30.5.2021.

(C) Tidsskrift for Den norske legeforening 2020. Lastet ned fra tidsskriftet.no 